\title{
Treatment with pirfenidone for two years decreases fibrosis, cytokine levels and enhances CB2 gene expression in patients with chronic hepatitis $C$
}

Lucia Flores-Contreras', Ana S Sandoval-Rodríguez', Mayra G Mena-Enriquez', Silvia Lucano-Landeros', Inmaculada Arellano-Olivera ${ }^{1,2}$, Arnulfo Álvarez-Álvarez ${ }^{1}$, M Guadalupe Sanchez-Parada ${ }^{1}$ and Juan Armendáriz-Borunda ${ }^{1,3^{*}}$

\begin{abstract}
Background: The aim of this study was to assess whether two-years treatment with Pirfenidone influences necroinflammation, fibrosis and steatosis, serum levels of TGF- $\beta 1$, IL-6, TNF- $a$ and CB1 and CB2 gene expression, in patients with chronic hepatitis C (CHC).

Methods: Twenty-eight patients out of 34 with $\mathrm{CHC}$ virus infection were enrolled in the study and received Pirfenidone (1200 mg/day) for 24 months. Six patients dropped out after 12 months of PFD. Liver biopsies and serum samples were obtained at the beginning and end of treatment. Modified HAI was calculated. CB1 and CB2 gene expression was correlated with fibrosis progression alongside with necroinflammation and steatosis. TGF- $\beta 1$, IL-6, TNF- $\alpha$ and liver transaminases were measured in serum at two-months intervals. HCV genotype and viral load were also assessed. Quality of life was evaluated by SF36 questionnaires and the prognosis of disease was assessed with Child-Pugh score. The Wilcoxon test matched-pair signed ranks were used to analyze the outcomes.
\end{abstract}

Results: Intention to treat analyses were performed for biochemistry and clinical parameters. At the end of treatment, necroinflammation grading was reduced in an average of 3.2 points in $82 \%$ of patients $(p<0.05)$ and Ishak's fibrosis stage decreased 2-points average in $67 \%$ of patients $(p<0.05$ ). Steatosis decreased in $61 \%$ of patients. IL-6 and TGF- $\beta 1$ serum levels decreased significantly in $93 \%$ and $67 \%$ of patients $(p<0.05)$, respectively, while TNF- $a$ diminished in 47\% of patients. ALT and AST tended to normalize in 81\% of patients; CB2 mRNA levels increased in $86 \%$ and CB1 expression diminished in $29 \%$ of patients. Both, quality of life and Child-Pugh score improvements were reported in all patients.

Conclusions: Pirfenidone for two years benefits CHC patients and improves inflammation, fibrosis and steatosis in higher number of patients as previously shown for 12-months treatment with PFD. Additionally, PFD improved TGF $\beta 1$ and IL-6 levels and diminished liver expression of anti-fibrogenic receptor CB2.

Trial registration: ClinicalTrials.gov identifier: NCT02161952. Protocol Registration Date: 06/11/2014.

Keywords: Pirfenidone, Liver fibrosis, Necroinflammation, Cytokines, Cannabinoid receptor 1, Cannabinoid receptor 2, Chronic hepatitis C

\footnotetext{
* Correspondence: armdbo@gmail.com

'Departamento de Biología Molecular y Genómica, Instituto de Biología

Molecular en Medicina y Terapia Génica, CUCS, Universidad de Guadalajara,

Sierra Mojada \# 950, Guadalajara, Jalisco 44281, Mexico

${ }^{3}$ INNOVARE, Guadalajara, Jalisco, Mexico

Full list of author information is available at the end of the article
} 


\section{Background}

Chronic hepatitis $\mathrm{C}(\mathrm{CHC})$ is one of the most common etiologies for liver fibrosis and will eventually progress to cirrhosis or even to hepatocellular carcinoma [1,2]. Nowadays, it is estimated that up to $3 \%$ of the world population is affected by $\mathrm{CHC}$, thus, a great deal of drugs designed to clear the liver from the infectious viral component in this disease, have been developed [2-6]. Nevertheless, fibrotic sequels eventually leading to dysfunctional liver activity in these patients are far from being resolved. In this frame of mind, pirfenidone (PFD) (5 methyl-1-phenil-2 (1H)-pyridone) has proved antifibrotic and anti-inflammatory properties in a wide number of animal models of fibrosis. PFD effects are mediated in part through inhibition of NF- $\mathrm{K}-\mathrm{B}$ activation, these mechanisms included inhibition of PDGF, hepatic stellate cells (HSC) proliferation, reduction of TNF- $\alpha$ and IFN- $\alpha$ levels and decrease in iNOS/NO induction [7,8]. Also, PFD down-regulates TGF- $\beta 1$, TIMP-1, MMP-2 mRNA and collagen deposition $[9,10]$. Previously, our group demonstrated that one-year treatment with $1200 \mathrm{mg} /$ day of oral PFD to patients with established liver fibrosis, decreased liver necroinflammation, steatosis and at less extent, fibrosis. Collagen I, TGF- $\beta 1$ and TIMP- 1 mRNAs were also downregulated [11]. Among the many factors known to influence hepatic fibrosis progression (gender, age at $\mathrm{HCV}$-infection, alcohol consumption), cannabinoids consumption has also been studied [12-14]. Recently, Zampino and cols. have highlighted that HCV-related clinical conditions like fibrosis, cirrhosis and hepatocellular carcinoma are the result of liver and systemic chronic inflammation [15]. On the other hand, cannabinoids signal through a G protein-coupled receptors called CB1 and CB2 which are absent or expressed in low levels in non injured livers, but strongly upregulated in fibrotic-liver, especially in hepatic myofibroblasts and vascular endothelial cells [16-18]. Several studies have shown that endogenous and exogenous cannabinoid ligands and their receptors play a key role in the pathogenesis of chronic liver injury [19-21]. Based in our previous report [11], we aimed in this work to implement a 24 months clinical protocol with $1200 \mathrm{mg} /$ day of oral PFD to analyze its effect in CB1 and CB2 cannabinoid receptors expression, serum levels of IL-6, TNF- $\alpha$, TGF- $\beta 1$ and necroinflammation and fibrosis scores. We reasoned that fibrosis stage in liver tissue from patients with $\mathrm{CHC}$ reported in this communication deserved further consideration, since an extended period with PFD treatment could result in an enhanced resolution of fibrosis as determined by liver biopsy. Furthermore, a couple of interesting articles recently published on the use of PFD in the treatment of two fibrotic diseases as diabetic nephropathy and pulmonary fibrosis suggest that PFD improves organ functionality demonstrating a benefit when it is used to treat fibrotic human pathologies [22,23]. Specifically, this very interesting study entitled "A Phase 3 Trial of Pirfenidone in Patients with Idiopathic Pulmonary Fibrosis" deserves a further and careful consideration [23].

\section{Methods \\ Patients}

Consecutive patients seen in our department were enrolled if they met the following criteria: (1) patients with established advanced liver disease caused by hepatitis $C$ virus chronic infection defined by a positive test for anti-HCV antibodies and detectable serum HCV RNA (Amplicor HCV 2.0 PCR test system; Quest Diagnostic, San Juan Capistrano, CA, USA) (2) signing of an informed consent form to allow collection of liver biopsies before and after (3) no anti-fibrotic, antiviral or immunosuppressive drugs for at least 6 months before starting pirfenidone therapy; and (4) no alcohol intake and non-smokers of cannabis for at least 6 months before nor during PFD treatment. The baseline period was defined as an observational period before pirfenidone therapy and each patient was used as its own control.

The no-inclusion criteria were the following: (1) evidences for other forms of liver diseases (2) co-infection with hepatitis B virus or HIV; (3) post-transplant patients; (4) known intolerance to pirfenidone; (5) pregnancy or breastfeeding; (6) gastrointestinal bleeding; (7) malignancy; and (8) patients with concomitant disease such as heart failure, coronary artery disease, diabetes or cancer.

\section{Study design}

This is an open-label, non-controlled and non-randomized clinical trial, designed to be carried out for 24 months in patients with chronic hepatitis $\mathrm{C}(\mathrm{CHC})$. The trial site was Institute of Molecular Biology in Medicine and Gene Therapy, University of Guadalajara, Mexico.

In this study 34 patients older than 18 years of age were enrolled, which had not previously participated in any other clinical protocol. Enrolled patients provided a medical history; complete physical examination was performed and intravenous blood was collected to assess liver function, liver fibrosis markers, complete blood count, blood coagulation profile, urinalysis, electrolytes status and serology (HCV, HBV, and HIV). HCV genotype was determined by LIPA (Quest Diagnostic, San Juan Capistrano, CA, USA) and HCV viral load was measured by PCR Quant (Amplicor HCV 2.0 PCR test system of Quest Diagnostic, San Juan Capistrano, CA, USA). Results were expressed as $\log 10 \mathrm{IU} / \mathrm{mL}$. Abdominal ultrasonography with Doppler assessment and computed tomography scan were performed to assess ascites and liver disease and portal system. Child-Pugh score was used to evaluate the severity of liver disease in all patients. Age at $\mathrm{HCV}$ infection, source of contamination and body mass index (BMI) were determined. Duration of $\mathrm{HCV}$ infection 
was estimated as the difference between the date of infection and the date of baseline liver biopsy. Two liver biopsies were obtained; one at baseline and a second one after two years of treatment.

Pirfenidone was administered three times a day in the form of $400 \mathrm{mg}$ capsules manufactured according to standard good manufacturing practices (GMPs); good laboratory practices (GLPs) and sanitary regulations enforced by the Federal Commission for Protection against Sanitary Risks (COFEPRIS).

During the study, patients had twelve medical visits during a 24 months period, in which patients were physically examined, adverse event story was collected and laboratory testing was realized. Patients also completed the 36 item Short-Form Health Survey (SF-36). Health survey was applied to evaluate quality of life in patients before and after PFD treatment with their own initial data as control.

This safety/efficacy, nonrandomized, self-monitored, open phase study was approved by Ethical Committee from Hospital Civil de Guadalajara with registration number 505/05 and the COFEPRIS (Mexican Ministry of Health) with registry number 05330020020126. Furthermore, the protocol was registered in ClinicalTrials.gov identifier: NCT02161952.

Also, this study was undertaken in accordance with the Declaration of Helsinki and with local laws and regulation applicable to the use of drugs in Mexico, and all patients gave informed consent.

\section{Medication}

Pirfenidone was supplied orally in $400 \mathrm{mg}$ gel capsules three times daily (every 8 hours) for a full dosage of $1200 \mathrm{mg}$ daily. All patients were instructed to take pirfenidone 20 minutes after meals to minimize gastrointestinal symptoms during 24 months. Patient's compliance of drug intake was assessed using specifically designed drug registration sheets.

\section{Biomarker analysis}

Biomarkers were analyzed in plasma from samples collected at baseline visit and end of study visits. Blood biomarkers measured were IL- 6 , TNF- $\alpha$ and TGF- $\beta 1$. Cytokine analysis was measured using a conventional automated analyzer (Sincron-Cx7 analyzer) and pre-coated ELISA assay ( $R$ \& D Systems, Minneapolis, MN, USA). All ELISA kits were utilized as described by the manufacturers.

\section{Liver histopathology}

Liver biopsy was obtained before starting treatment with pirfenidone and second liver biopsy after two years of treatment using Color Doppler Sonography NeedleGuided. Liver biopsy specimens were fixed in formalin, embedded in paraffin, and stained with hematoxylin-eosin
(H\&E) and trichromic Masson. Fibrosis and necroinflammation were analyzed according to the Modified histological activity index (HAI) of Ishak scoring system [24]. Hepatic steatosis was measured according to the percentage of fat vacuoles in 20 random fields using a computerassisted automated image analyzer (Image Pro-Plus 5.0, Media Cybernetics, Inc, Bethesda, MD, USA). Necroinflammation was scored by the activity index on a scale of 0 to 18. Fibrosis was staged on a scale of 0 to 6 (F0 or F6, F6 defining cirrhosis) with fibrosis stage of 4 or 5 defined as severe or advanced fibrosis. The $50 \%$ of patients enrolled in this study displayed advanced liver fibrosis (stage 4-5); 30\% of patients had cirrhosis (stage 6) at the beginning of the trial and the $20 \%$ of them displayed mild or moderate liver fibrosis (stage 1-3).

\section{RT-PCR analysis}

A portion of liver biopsy was frozen for RT-PCR analysis. Total RNA from liver biopsy was extracted using Trizol reagent according to the manufacturer instructions (Invitrogen, Carlsbad, CA, USA). RNA was quantified using spectophotometry. Reverse transcription was performed with $2 \mu \mathrm{g}$ of total RNA for all genes with the cDNA synthesis kit (Cat. 4368814). Using $240 \mathrm{ng}$ of random primer, $2 \mathrm{U}$ RNAse inhibitor, $5 \mathrm{mM}$ of DTT, $1 \mathrm{mM}$ of dNTPs and 200U of transcriptase, PCR was performed using the following protocol: $65^{\circ} \mathrm{C} / 5 \mathrm{~min}$, $4^{\circ} \mathrm{C} / 5 \mathrm{~min}, 25^{\circ} \mathrm{C} / 5 \mathrm{~min}, 50^{\circ} \mathrm{C} / 60 \mathrm{~min}, 70^{\circ} \mathrm{C} / 15 \mathrm{~min}$ and $4^{\circ} \mathrm{C} / 5 \mathrm{~min}$.

Quantitative real time PCR was performed using a Rotor Gene 3000 Termocycler (Corbett Research, Cambridge shire, UK) under the following conditions: 1 hold for $2 \mathrm{~min}$ at $50^{\circ} \mathrm{C}, 1$ hold for $5 \mathrm{~min}$ at $94^{\circ} \mathrm{C}$, and 45 cycles of $30 \mathrm{sec}$ at $94^{\circ} \mathrm{C}$ and $40 \mathrm{sec}$ at $60^{\circ} \mathrm{C}$. Specific primers for CB1 and CB2 were acquired from Applied Biosystems, NJ, USA. GAPDH was used as housekeeping gene. For the reaction, $2 \mu \mathrm{l}$ of cDNA was used in $5 \mu \mathrm{l}$ of Mix, $0.5 \mu$ of TaqMan probe and primers for CB1 (Cat\#:Hs00275634_m1), CB2 (Cat\#:Hs00361490_m1) and GAPDH (Cat\#:Hs99999905_m1). Gene expression was calculated with the $2^{-\Delta \mathrm{CT}}$ method according to Livak et al [25].

\section{Statistical analysis}

Because values in baseline and treatment periods did not follow a parametric distribution, the Wilcoxon matchedpair signed ranks test was used to analyze the outcomes. Intention to treat analysis (ITT) was also performed. Data are presented as mean \pm SD for parametric data. Statistical analysis was performed using Prism software (GraphPad Prism, CA, USA) Significance was defined as a $P$ value $<0.05$. 


\section{Results}

\section{Study group characteristics}

34 patients enrolled with chronic hepatitis $C$ tolerated fairly well a dose of $1200 \mathrm{mg} /$ day of PFD. During this latter period, 6 of 34 patients (17\% drop-outs) were excluded from study for non-compliance or death (Table 1). These patients attended the protocol a range of 13 to 18 months. Therefore, the intention to treat analysis includes all of the 34 patients with $\mathrm{CHC}$, although only 28 patients ended treatment for 24 months. None of the patients dropped out from the study due to severe side effects of PFD (Table 2). Mean age for patients was $56 \pm$ 10 years and, as reported in other studies, females seemed more susceptible to be chronically infected with HCV (62\%) [26]. Median body mass index was $28 \pm 7$; while $36 \%$ of patients presented overweight and $43 \%$ were obese according to WHO criteria [27]. Median age at $\mathrm{HCV}$ exposure was 27 years old and 32 years was the mean infection period. Predominant HCV transmission route was blood transfusion since 30 out of 34 patients underwent one before 1989. Main HCV genotype was 1a y $1 \mathrm{~b}(70 \%)$, followed by genotypes $2 \mathrm{a}$ y $2 \mathrm{c}(12 \%)$, and $3 \mathrm{a}$ (6\%). Serum HCV viral load remained without significant changes throughout the study, since values did not modify more than one log, indicating no noticeable effect of PFD treatment in HCV replication. Patient characteristics are summarized in Table 3.

\section{Characteristics of dropping-out patients}

As previously stated, of the initial 34 patients enrolled, six patients stopped therapy after at least 1 year of therapy due to non-compliance or death. Reason for death and non-compliance were not related to pirfenidone secondary effects. Deaths were due to advance liver disease complications like hepato-renal syndrome (1 patient, Child-Pugh C), hepatocarcinoma (1 patient, Child-Pugh B), esophagic varices bleeding (1 patient, Child-Pugh B) or non-related to liver disease like heart attack (1 patient, Child-Pugh A). Two patients stop attending the trial since they were from out state Jalisco (Child-Pugh A) (Table 4).

Table 1 Causes of Death in patients enrolled in the study

\begin{tabular}{lcc}
\hline & \multicolumn{2}{c}{ Number of patients } \\
\cline { 2 - 3 } Duration of treatment & $<\mathbf{1}$ year & $>\mathbf{1}$ year \\
\hline Treatment-related mortality & - & - \\
Hepatocarcinoma & - & 1 \\
Hepato-renal syndrome & - & 1 \\
Esophagic varices bleeding & - & 1 \\
Heart attack & - & 1 \\
Percent of enrolled patients death & $0 \%$ & $9 \%$ \\
\hline
\end{tabular}

Note: 2 patients were excluded from the study due to lack of monitoring.
Table 2 Secondary effects associated with pirfenidone treatment for two years

\begin{tabular}{lllll}
\hline Symptoms & ${ }^{*} \boldsymbol{n}=\mathbf{2 8}$ & $\mathbf{\%}$ & ${ }^{* *} \boldsymbol{n}=\mathbf{3 4}$ & $\mathbf{\%}$ \\
\hline Gastritis & 17 & $81 \%$ & 23 & $67 \%$ \\
Nausea & 10 & $48 \%$ & 12 & $35 \%$ \\
Rash & 10 & $48 \%$ & 10 & $29 \%$ \\
Photosensitivity & 3 & $14 \%$ & 3 & $9 \%$ \\
Headache & 3 & $14 \%$ & 4 & $12 \%$ \\
Vomiting & 1 & $5 \%$ & 1 & $3 \%$ \\
Dizziness & 2 & $10 \%$ & 2 & $6 \%$ \\
Weakness & 2 & $10 \%$ & 2 & $6 \%$ \\
Insomnia & 1 & $5 \%$ & 1 & $3 \%$ \\
Somnolence & 1 & $5 \%$ & 1 & $3 \%$ \\
\hline
\end{tabular}

*Data in the 28 patients that conclude the study. Some patients presented more than one secondary effect.

**The most common side secondary effect in the 34 enrolled patients including the 6 drop-out patients were gastritis, nausea and rash, these effects disappeared after 3 months of treatment.

\section{Effect of PFD on liver biochemistry and clinical data}

AST and ALT and bilirubins in serum showed elevated values at enrollment suggesting active hepatic damage. All biochemical parameters tend to decrease after treatment. $81 \%$ of patients (28) who completed treatment for two years reduced enzyme values compared to their own initial data. Statistically significant reduction was achieved in AST $(94 \pm 55$ versus $75 \pm 38 \mathrm{UI} / \mathrm{mL} ; \mathrm{p}<0.05)$ while ALT reduced from $85 \pm 71$ to $65 \pm 34 \mathrm{UI} / \mathrm{mL}$; the levels of total bilirubin diminish from $1 \pm 0.8$ to $1 \pm 0.5$

Table 3 General characteristics of patients

\begin{tabular}{|c|c|c|}
\hline Characteristics & & $n=34$ \\
\hline \multirow[t]{2}{*}{ Sex } & Male, n (\%) & $13(38 \%)$ \\
\hline & Female, n (\%) & $21(62 \%)$ \\
\hline Age at exposure (yr) & Mean \pm SD & $27 \pm 9$ \\
\hline $\begin{array}{l}\text { Age at liver biopsy before } \\
\text { treatment (yr) }\end{array}$ & Mean \pm SD & $56 \pm 10$ \\
\hline $\begin{array}{l}\text { Age at liver biopsy after } \\
\text { treatment (yr) }\end{array}$ & Mean \pm SD & $58 \pm 10$ \\
\hline \multirow[t]{2}{*}{ Route of transmission } & Blood transfusion, n (\%) & $29(85 \%)$ \\
\hline & Nosocomial, n (\%) & $5(15 \%)$ \\
\hline Duration of HCV exposure (yr) & Mean \pm SD & $32 \pm 10$ \\
\hline \multirow[t]{4}{*}{ HCV genotype } & Genotype 1, n (\%) & $24(70 \%) \&$ \\
\hline & Genotype 2, n (\%) & $4(12 \%) \&$ \\
\hline & Genotype 3, n (\%) & $2(6 \%)$ \\
\hline & $\mathrm{ND}, \mathrm{n}(\%)$ & $5(15 \%)$ \\
\hline \multirow{2}{*}{$\begin{array}{l}\text { Change in HCV viral load } \\
\text { after treatment }\end{array}$} & Increase 1 log, n (\%) & $1(4 \%)$ \\
\hline & Unchanged, n (\%) & $27(96 \%)$ \\
\hline Body mass index $\left(\mathrm{Kg} / \mathrm{m}^{2}\right)$ & Mean $( \pm S D)$ & $28 \pm 7^{* *}$ \\
\hline
\end{tabular}

\&A patient presented co-infection with two genotypes of VHC. "Unchanged: modification less than 1 log in viral load; * Overweight according to OMS; ND: not determined. HCV: Hepatitis C virus. 
and indirect bilirubin $0.8 \pm 0.7$ to $0.6 \pm 0.4$ between initial mean values and after treatment mean values of all patients (Table 5).

\section{Child-Pugh score in enrolled patients}

Child-Pugh score was measured in order to indirectly assess the prognosis of chronic liver disease and to correlate with patient survival at two years [28]. The 28 patients that concluded the two-year treatment showed an improved score at the end of the study (Table 4). Hepatitis $C$ patients with established liver fibrosis after PFD treatment had improved Child-Pugh score compared to initial values as seen in Table 4. Treatment allowed patients to remain in a compensated status, since 20 out of 28 patients experienced no change in Child-Pugh A or B score, $5 / 28$ improved their score and only 3 patients decreased Child-Pugh score indicating most severe liver damage. However, when drop-out patients were included, no statistical significance was achieved in this score.

\section{Intention to treat analysis for quality of life}

SF-36 is one of the questionnaires most recognized to monitor quality of life. The intention to treat analysis for the quality of life showed scores in SF-36 significantly higher in all enrolled patients compared at the end and baseline of treatment, demonstrating that quality of life improved in $97 \%$ of them as described in Table 6. Data for the diverse domains of the questionnaire in the 34 patients enrolled were as follows: physical function $82 \pm$ 23 , physical role $86 \pm 31$, body pain $82 \pm 19$, general health $73 \pm 18$, vitality $73 \pm 22$, social role $81 \pm 23$, emotional role $83 \pm 38$, and mental health $83 \pm 17$. All parameters improved at the end of the treatment.

\section{Secondary effects}

Pirfenidone was well tolerated. All patients tolerated the dosage of $1200 \mathrm{mg} /$ day from the beginning of the treatment; seven patients did not develop any secondary effect. Table 2 summarizes secondary effects known to be associated with pirfenidone for 27/34 patients that showed any or several of them. Patients developed negligible secondary effects, like gastritis (23/34 patients; $64 \%$ $\%)$, nausea (12/3 patients; 35\%) among others. These secondary effects disappeared 3 months after initiating PFD intake. None of patients dropped out of the study due to side effects of treatment. All patients that conclude the study adhered to treatment (they received $\geq 80 \%$ of scheduled doses).

\section{PFD effect in liver histopathology}

At the end of 24 months of treatment, necroinflammation score was reduced an average of 3.2 points in $82 \%$ of patients $(\mathrm{p}<0.01)$ and fibrosis decreased in $67 \%$ of patients by 2-point average according to Ishak's staging. Representative photographs of liver biopsy from one patient before and after treatment are shown in Figure 1. Initially, hepatic fibrosis with regenerative nodules and necroinflammation was observed, while after two-year PFD treatment H\&E staining indicates that necroinflammation decreases since inflammatory cells infiltration is reduced along with an improvement in tissue morphology (Figure 1A). Necroinflammation grading graph shows reduction in the mean value obtained from all patients after PFD treatment compared to initial data (Figure 1C). Before treatment, patient necroinflammation grading ranged between 8 and 16 and after PFD treatment, classifications reduced to 6-11 points. Liver fibrosis was markedly attenuated after PFD treatment in $67 \%$ of patients compared to their own initial scores (Figure 1B). In these patients, quantitative analysis of fibrosis demonstrated a significant reduction from $4.8 \pm 1.1$ to $2.8 \pm 0.7$ points in the median fibrosis Ishak stage $(\mathrm{p}<0.05)$. Patients with reduced fibrosis showed mild fibrosis after treatment as observed in trichromic Masson staining that displayed a noticeable diminution in fibrotic septums where extracellular matrix is reduced in thickness

Table 4 Severity of disease according to child-pugh score

\begin{tabular}{|c|c|c|c|c|c|}
\hline \multirow[b]{2}{*}{ Treatment } & \multirow[b]{2}{*}{ No. patients } & \multirow[b]{2}{*}{ Statistics } & \multicolumn{2}{|c|}{ Child-pugh score } & \multirow[b]{2}{*}{$P$ value } \\
\hline & & & Before & After & \\
\hline \multirow[t]{3}{*}{$<2$ years } & 6 & Minimum & $5(A)$ & $6(A)$ & 0.2 \\
\hline & & Median & $6.5(A)$ & $9(B)$ & \\
\hline & & Maximum & $10(C)$ & $9(\mathrm{~B})$ & \\
\hline \multirow[t]{3}{*}{2 years } & 28 & Minimum & $5(A)$ & $5(A)$ & 0.8 \\
\hline & & Median & $5.5(\mathrm{~A})$ & $6(A)$ & \\
\hline & & Maximum & $10(C)$ & $12(C)$ & \\
\hline \multirow[t]{3}{*}{ Intention to treat } & 34 & Minimum & $5(A)$ & $5(A)$ & 0.6 \\
\hline & & Median & $6(A)$ & $6(A)$ & \\
\hline & & Maximum & $10(C)$ & $9(\mathrm{~B})$ & \\
\hline
\end{tabular}


Table 5 Biochemical measurements of patients

\begin{tabular}{|c|c|c|c|c|c|c|c|c|c|}
\hline Treat & & $<2$ years & & & 2 years & & & ntion to $\mathrm{t}$ & \\
\hline No. patients & & 6 & & & 28 & & & 34 & \\
\hline Biochemical data & Before & After & $P$ value & Before & After & $P$ value & Before & After & $P$ value \\
\hline $\mathrm{ALT}($ mean $\pm \mathrm{SD})$ & $67 \pm 25$ & $59 \pm 20$ & 0.63 & $85 \pm 71$ & $65 \pm 34$ & 0.13 & $82 \pm 68$ & $64 \pm 32$ & 0.23 \\
\hline AST $($ mean $\pm S D)$ & $95 \pm 38$ & $87 \pm 38$ & 1.0 & $94 \pm 55$ & $75 \pm 38$ & $0.02^{*}$ & $94 \pm 54$ & $78 \pm 38$ & $0.02^{*}$ \\
\hline Total Bilirubin (mean \pm SD) & $2 \pm 1.7$ & $3.1 \pm 1.5$ & 0.16 & $1 \pm 0.8$ & $1 \pm 0.5$ & $0.04^{*}$ & $1.4 \pm 0.9$ & $1.4 \pm 1.1$ & 0.46 \\
\hline Direct Bilirubin (mean $\pm \mathrm{SD}$ ) & $0.8 \pm 0.5$ & $1.5 \pm 0.9$ & $0.03^{*}$ & $0.4 \pm 0.3$ & $0.4 \pm 0.2$ & 0.63 & $0.5 \pm 0.3$ & $0.6 \pm 0.6$ & 0.46 \\
\hline Indirect Bilirubin (mean \pm SD) & $1.3 \pm 0.9$ & $1.6 \pm 0.9$ & 0.56 & $0.8 \pm 0.7$ & $0.6 \pm 0.4$ & $0.05^{*}$ & $0.9 \pm 0.7$ & $0.8 \pm 0.6$ & 0.31 \\
\hline
\end{tabular}

ALT: Alanine transaminase; AST: Aspartate transaminase. * $\mathrm{p}<0.05$.

(Figure 1D). Besides, steatosis was detected in thirteen patients. Steatosis has been associated with progression of liver fibrosis. Figure $1 \mathrm{E}$ shows representative images of steatosis improvement achieved in representative patient number eleven. Steatosis was quantitatively measured showing a significant reduction in most patients evaluated. In these patients, a significant reduction in steatosis was achieved $(p<0.01)$ from $4.9 \%$ to $1.24 \%$ after treatment. In Figure $1 \mathrm{~F}$ steatosis data for each patient is presented as percentage of total stained area. Previously, we reported that one-year treatment with PFD rendered reduced necroinflammation and fibrosis, as well as, steatosis in patients with advanced established liver fibrosis. Now, in this study we demonstrated that two year-treatment with PFD is more effective achieving a major decrease in necroinflammation, fibrosis and steatosis.

\section{Effects of PFD on biomarkers}

In order to correlate our histologic results with serum markers, pro-inflammatory cytokines IL- 6 and TNF- $\alpha$ were analyzed. Figure 2A shows that IL-6 serum levels decreased significantly in $93 \%$ of patients from $4.7 \pm$ $4.9 \mathrm{pg} / \mathrm{mL}$ before treatment to $2.0 \pm 3.9 \mathrm{pg} / \mathrm{mL}$ after treatment $(\mathrm{p}<0.01)$. In Figure $2 \mathrm{~B}$ TNF- $\alpha$ serum levels are shown. Unexpectedly, we did not find changes after PFD treatment. This might be due to the sensitivity of the methodology used. Experiments are undergoing to overrule this possibility. TGF- $\beta 1$, the emblematic pro-

Table 6 Intention-to-treat analysis for quality of life

\begin{tabular}{llll}
\hline Domains (mean \pm SD) & SF-36* before & SF-36* after & P value \\
\hline Physical function & $69 \pm 30$ & $82 \pm 23$ & $0.00^{* *}$ \\
Role physical & $61 \pm 47$ & $86 \pm 32$ & $0.02^{* *}$ \\
Body pain & $70 \pm 26$ & $81 \pm 19$ & $0.00^{* *}$ \\
General health & $55 \pm 21$ & $73 \pm 18$ & $0.00^{* *}$ \\
Vitality & $62 \pm 24$ & $73 \pm 22$ & $0.02^{* *}$ \\
Social functioning & $73 \pm 29$ & $81 \pm 23$ & $0.03^{* *}$ \\
Role emotional & $68 \pm 45$ & $83 \pm 38$ & 0.17 \\
Mental health & $75 \pm 20$ & $83 \pm 17$ & $0.00^{* *}$ \\
\hline
\end{tabular}

*SF-36: Short-Form Health Survey with 36 questions. ${ }^{* *} \mathrm{p}<0,05$. fibrogenic cytokine showed a trend to diminish in $67 \%$ of patients as seen in Figure $2 \mathrm{C}$. TGF- $\beta 1$ values were down regulated from $501.9 \pm 442.4 \mathrm{pg} / \mathrm{mL}$ before treatment to $204.5 \pm 174.2 \mathrm{pg} / \mathrm{mL}$ after treatment showing statistical significance against initial levels $(\mathrm{p}<0.05)$.

\section{PFD effect on CB1 and CB2 receptors gene expression}

Real time PCR was used to detect gene expression of key molecules involved in fibrosis progression. CB1 and CB2 dynamically participate in liver fibrosis, CB1 is considered pro-fibrogenic and its blockade has shown fibrosis reduction, while inducing CB2 signaling leads to anti-fibrogenic effects $[19,29]$. We detected cannabinoid receptors $\mathrm{CB} 2$ and $\mathrm{CB} 1 \mathrm{mRNA}$ levels in liver samples in order to analyze any possible effect of PFD treatment over these molecules. Expression of cannabinoid receptors CB1 and CB2 was detected in all patients analyzed. CB1 gene expression demonstrated a tendency to diminish at the end of treatment in $28.5 \%$ of patients with 4.7 fold decrease (Figure 3A). Although the statistic test used did not allow us to conclude significance on this issue, tendency of CB1 to decrease is clear. On the other hand, CB2 receptor gene expression augmented a 5.4 fold-increment in $85.7 \%$ of patients after treatment (Figure 3B). In these patients, statistical significance reached a $\mathrm{p}<0.05$ compared to initial values.

\section{Discussion}

Our group has demonstrated that PFD is an antiinflammatory and anti-fibrogenic agent in experimental models of cirrhosis [9] and in humans affected with hepatic fibrosis caused by different etiologies [11,30-32]. Moreover, PFD has shown to improve necroinflammation, steatosis and liver regeneration in a sub-set of patients with established advanced liver fibrosis caused by HCV infection [11]. It had also been demonstrated that PFD has an anti-fibrogenic action inhibiting capsular contracture in mammary implants and an antioxidant role in different experimental models of cirrhosis [31-33]. Moreover, two randomized, double-blind, multicentre studies recently published; used PFD in the treatment of pulmonary fibrosis and diabetic nephropathy, pointing out the relevance of 


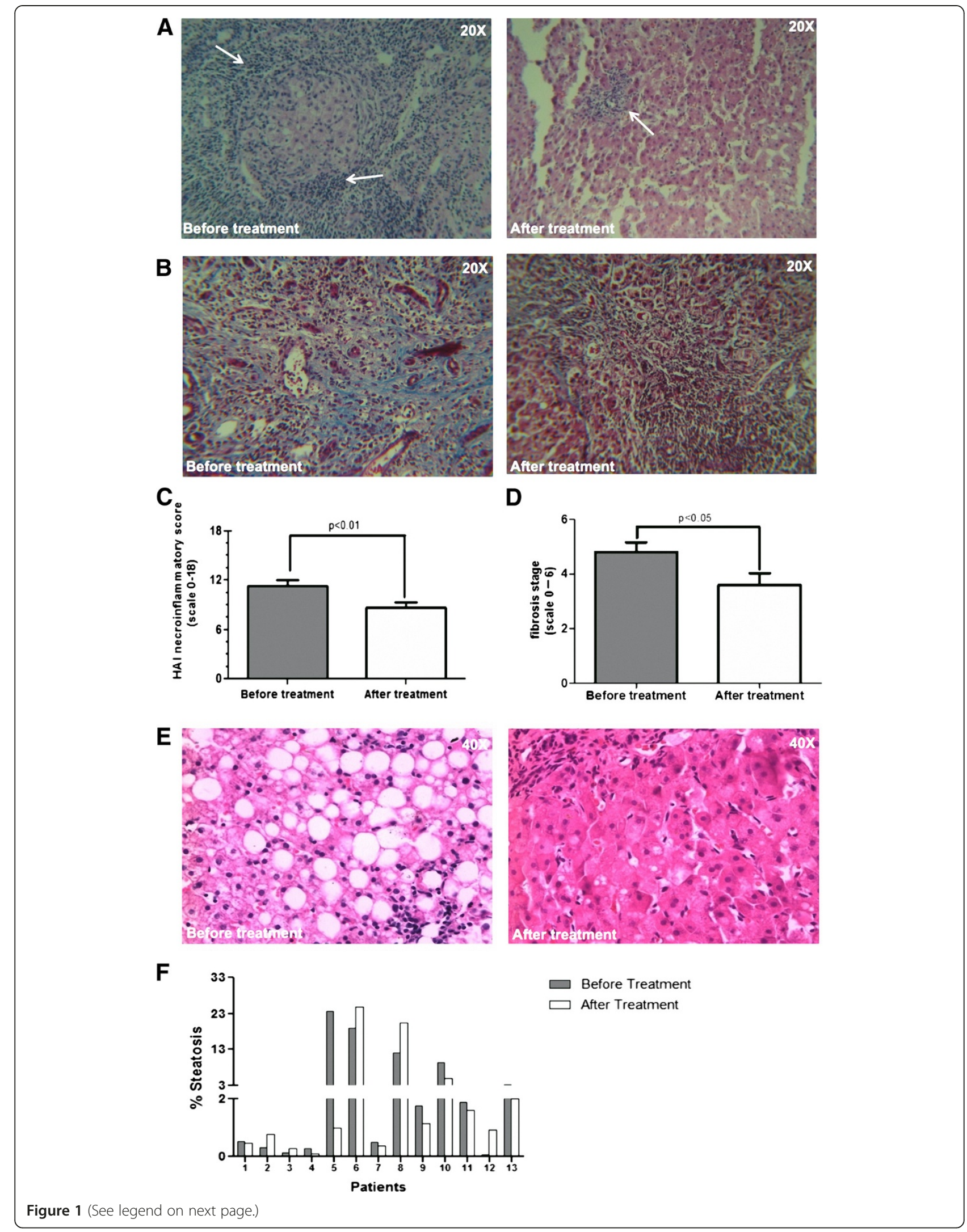


(See figure on previous page.)

Figure 1 Pirfenidone treatment decreases necroinflammation grade, fibrosis stage and steatosis. Representative photomicrographs of liver biopsy were stained with H\&E showing necroinflammation (A) and trichromic Masson staining for fibrosis (B) before and after of treatment. In (A) arrows indicate that inflammatory cell infiltrate is reduced post-treatment. In (B) collagen fibers clearly are reduced after PDF treatment. (C) Graph indicates mean \pm SD initial and final values for necroinflammation grade that reduced an average of 2.6 points in $81.8 \%$ of patients ( $p<0.01$ ). Mean \pm SD initial and post-treatment fibrosis stage is represented in (D); stage decreased 2 points as average in $67 \%$ of patients ( $p<0.05$ ) by the end of treatment. (E) Representative sections of liver tissue were stained with H\&E to determine steatosis area. Representative microphotographs (patient 05) showed before treatment macro-steatosis and micro-steatosis, and an obvious decline in steatosis is evident by the end of treatment. (F) Individual data for percentage of steatosis indicates decrease in liver fat-area in 8/13 patients, while in 5/13 patients steatosis remains.

PFD in the clinical scenario when it comes to treat patients with these fibrotic illnesses [22,23]. Moreover, in the present study we evaluated the effect of 24 months treatment with $1200 \mathrm{mg} / \mathrm{kg}$ of PFD in HCV chronically-infected patients to elucidate whether PFD therapy has an effect on serum expression of fibrogenic and pro-inflammatory molecules as well as other markers. At the molecular level, PFD possess a potent anti-TNF- $\alpha$ and anti-TGF- $\beta 1$ action and on other pro-inflammatory cytokines [34-36]. It has been confirmed in this two-years follow-up trial that IL-6 experienced a significant decrease in serum levels in most of patients as well. This fact indicates that the inflammatory pathway IL-6/TNF- $\alpha$ is being affected by PFD treatment. According to this, necroinflammation score also reduces in $82 \%$ of patients after treatment; a number that is significant greater than the $53.3 \%$ achieved with one-year treatment. Interestingly, we showed that 2-year PFD treatment compared to 1 -year treatment augments the number of patients that achieved fibrosis reduction (30\% in the one-year follow up vs. $67 \%$ in the two-year study). This improvement in liver fibrosis was histologically monitored using Ishak score, and a considerably 2-point decrease (mean value) in liver fibrosis score was achieved at the end of treatment compared with patients-initial data. This information correlates with observed reduction on serum levels of hepatic enzymes and bilirubin that reflects a functional restoration in the liver due to PFD treatment.

As known, steatosis is the result of the accumulation of fat in hepatocytes and it has been associated with rapid progression of liver fibrosis $[37,38]$. The percentage of patients that reduced fat-occupied liver area with 2 -year treatment was roughly the same as those in the one-year period (60\% vs 61.5\%). It is important to keep in mind, that studies have reported that agonist of CB1 receptor promotes steatosis and strong evidence argues for a steatogenic role of the cannabinoid system [14,39-41].
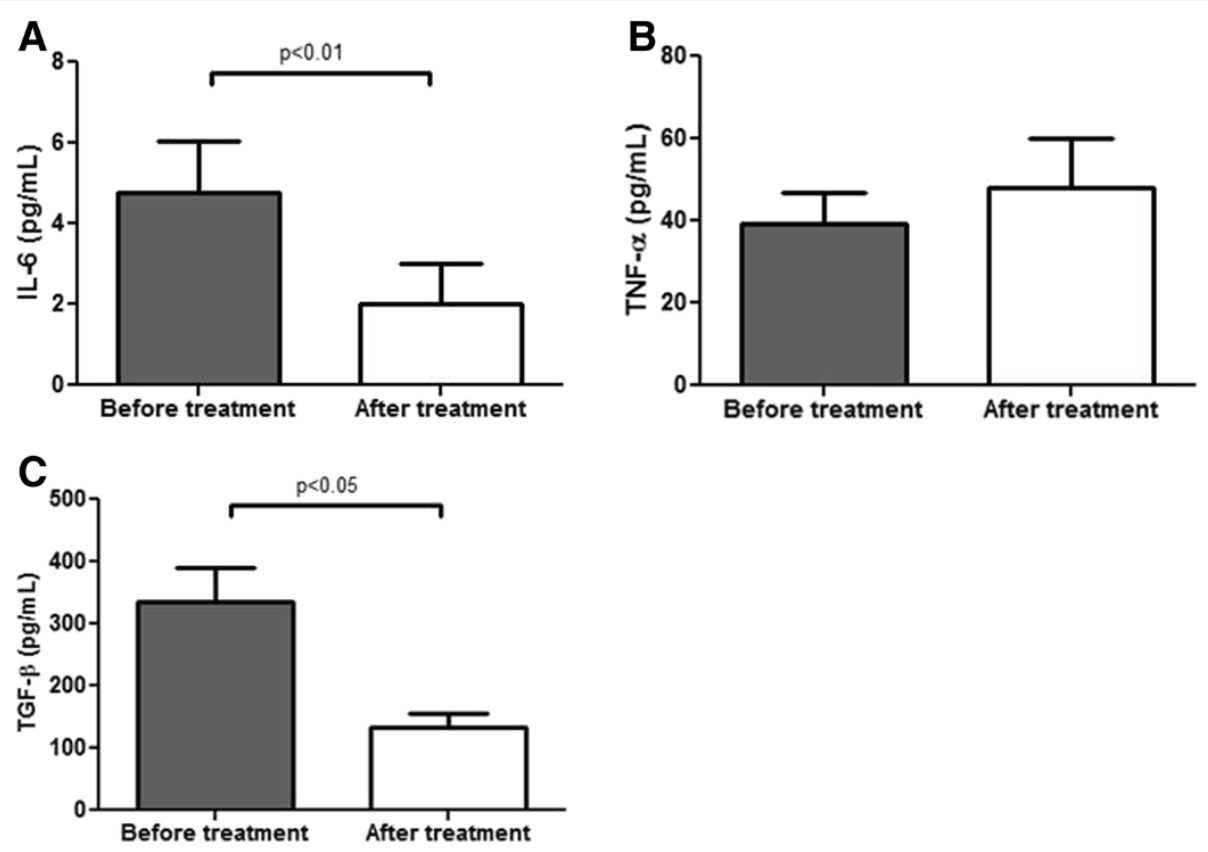

Figure 2 TGF- $\beta 1$ and cytokines serum levels in CHC patients before and after treatment with PFD. Quantitative analysis of cytokines was determined before and after PFD treatment. (A) After treatment IL-6 mean \pm SEM decreased reaching statistical significance $(p<0.05)$. In (B) graph indicates TNF-a mean \pm SEM in patients before and after treatment. (C) TGF- $\beta 1$ mean \pm SEM concentration of all patients after treatment $(p<0.05)$. 


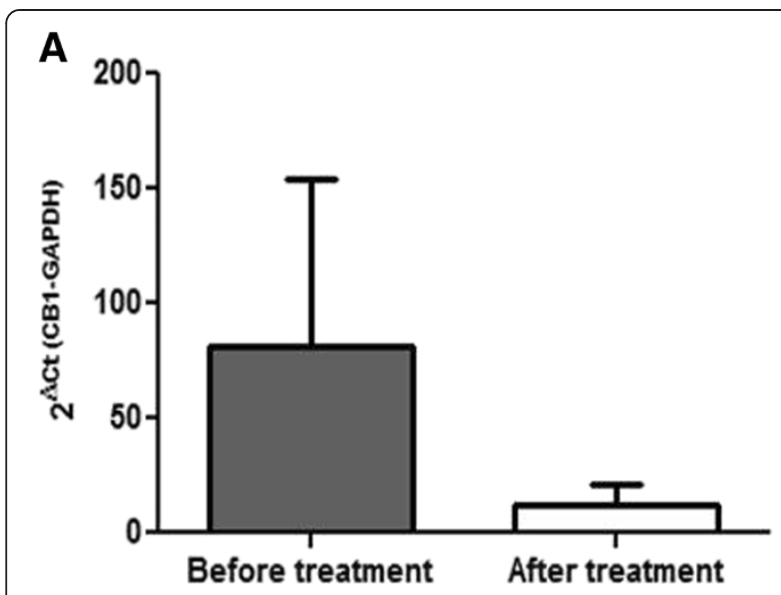

B

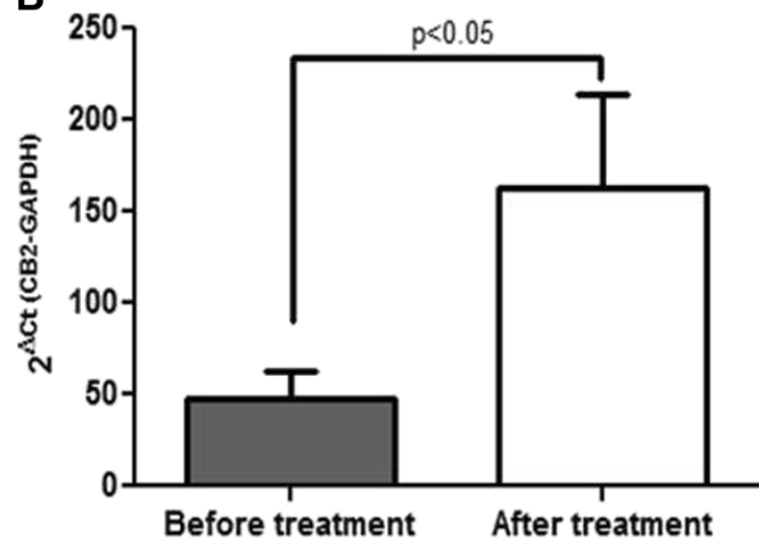

Figure 3 Gene expression of CB-1 and CB-2 in CHC patients. Messenger RNA levels of $C B 1$ and $C B 2$ receptors were analyzed by Real Time-PCR. In (A) mean \pm SD values of all patients analyzed for CB1 receptor are presented with no statistical change, in (B) a decrease after treatment was evident, CB2 receptor mRNA was significantly up-regulated $(p<0.05)$ in patients after treatment.

Therefore, histological findings in steatosis reduction can be related with diminution in CB1-mRNA levels observed in this study. In this framework, the endocannabinoid system plays an important role in liver fibrosis. In murine models of chronic liver-injury, CB1 receptor antagonism by pharmacological or genetic mechanisms reduced fibrotic area, TGF- $\beta 1$ expression and accumulation of fibrogenic cells [29]. In opposition to CB1 receptor antagonism effects, CB2 receptor agonist counteracts liver fibrosis and induces inhibition and apoptosis of hepatic myofibroblasts and stellate cells [19]. Thus, we looked at the effects of PFD therapy in the expression of these molecules. To our knowledge, this report is the first attempt to search for a possible relation between PFD and CB1 and CB2 mRNA expression. After treatment, patients showed CB1 mRNA reduced to almost half of the initial level (even when no statistical difference was obtained) demonstrating benefits of treatment associated with steatosis decline; while CB2 mRNA levels were over-expressed approximately by $50 \%$ which correlates with the improvement in fibrotic score and necroinflammation. In this context, results from Coppola et al. related to rs35761398 variant of CB2 receptor gene (CNR2) in Italian HCV-chronic infected patients, demonstrated that QQ allele is associated with more severe inflammation and hepatocellular necrosis. The influence of this polymorphism in the response to pirfenidone in Hispanic patients could be evaluated in future studies [42].

As reported, CBs liver expression can be detected mainly in hepatocytes and stellate cells $[19,29,43]$. In this protocol, CBs mRNAs were detected in liver homogenates. Thus, we believe this reflects the organ microenvironment that induces liver improvement. As observed, PFD was satisfactorily tolerated for the two-years period at $1200 \mathrm{mg} /$ day, given that $7 / 28$ patients did not develop any secondary effect and 21 patients developed just negligible side effects like gastritis, nausea and rash. Several limitations of the study must be recognized, though our findings strongly support that PFD reduces liver fibrosis, necroinflammation and steatosis. Also, treatment for a period of two years is well-tolerated and increasing time of treatment renders enhanced benefits as observed in this HCV-liver fibrosis patient cohort, i.e. recovering in hepatic markers, TGF- $\beta 1$ and pro-inflammatory cytokines serum levels reduction as well as, mRNA levels of CB2 mRNA increase.

\section{Conclusion}

In conclusion, there is an evident advantage of two-years treatment over the one-year period and administration of PFD induced only minor side effects, which were resolved after $2 / 3$ months of PFD intake. In addition, histopathologic results showed improvement in terms of the progression of fibrosis and stage of inflammation, as well as decrease in the percentage of steatosis after two years of treatment with PFD. Also, this study is the first to show that PFD decreases serum levels of TGF- $\beta 1$ and IL-6 and gene expression increases anti-fibrogenic CB2 receptor. However, it is important to remember that viral clearance is indispensable to cure the disease and to resolve liver damage. In this context, direct antiviral agents (DAA) and immune system boosters (some of them with proven efficacy) are the standard of care for chronic HCV infected patients. However, these treatments are not available for general population who is not covered under the social services (i.e. regular health care in North-America) in developing countries like Mexico. This is due to the elevated cost of such a treatments, which make them inaccessible to non-affiliated patients. Then, in this majority of untreated patients with DAA, an alternative anti-fibrogenic therapy could impact their health and quality of life. Besides, the combination of pirfenidone with DAAs can be useful in patients infected with genotypes that can be hardly 
eliminated with standard therapies and can also be evaluated in other liver diseases.

\section{Abbreviations}

ALT: Alanine transaminase; AST: Aspartate transaminase; BMI: Body mass index; CB1: Cannabinoid receptor 1; CB2: Cannabinoid receptor 2; CHC: Chronic Hepatitis C; GAPDH: Glyceraldehyde-3-phosphate dehydrogenase; HAI: Histological activity index; HCV: Hepatitis C virus; HIV: Human immunodeficiency virus; IL-6: Interleukin 6; INF-a: Interferon-alpha; iNOS: induced Oxide Nitric Synthetase; MMP-2: Matrix metalloproteinase-2; NF-KB: Nuclear factor kappa-light-chain-enhancer of activated B cells; NO: Nitric oxide; PFD: Pirfenidone; PDGF: Platelet-derived growth factor; RT-PCR: Real time- Polymerase chain reaction; TIMP-1: Tissue inhibitor of metalloproteinases-1; TGF- 31 : Tumor growth factor- beta1; TNF-a: Tumor necrosis factor-alpha.

\section{Competing interests}

Authors do not have anything to disclose regarding competing interest for this manuscript.

\section{Authors' contributions}

LFC: Principal author, article writing, sample processing, laboratory studies, analysis of results and statistics. ASR: Methodological analysis and article writing. MME: Laboratory tests and analysis of results. SLL: Protocol administration and clinical evaluation. IAO: Patient recruitment and clinical evaluation. AAA: Pathological analysis in liver biopsies. MGSP: Laboratory tests. JAB: Principal investigator, liver biopsies analysis, article writing and supervision. All authors read and approved the final manuscript.

\section{Acknowledgments}

Authors acknowledge CONACYT for the grant provided.

\section{Source of funding}

Juan Armendariz-Borunda received a grant (\#25474) from CONACYT (Science and Technology National Council).

\section{Author details}

'Departamento de Biología Molecular y Genómica, Instituto de Biología Molecular en Medicina y Terapia Génica, CUCS, Universidad de Guadalajara, Sierra Mojada \# 950, Guadalajara, Jalisco 44281, Mexico. ${ }^{2}$ Unidad Médica de Alta Especialidad, Hospital de Especialidades Centro Medico Nacional de Occidente, Guadalajara, Jalisco, Mexico. ${ }^{3}$ INNOVARE, Guadalajara, Jalisco, Mexico.

Received: 17 August 2013 Accepted: 14 July 2014

Published: 27 July 2014

\section{References}

1. Friedman SL: Liver fibrosis: from bench to bedside. J Hepatol 2003, 38:38-53.

2. Alter MJ: Epidemiology of hepatitis C virus infection. World J Gastroenterol 2007, 7:13(17):2436-2441.

3. Liang TJ, Rehermann B, Seeff LB, Hoofnagle JH: Pathogenesis, natural history, treatment, and prevention of hepatitis C. Ann Intern Med 2000, 132:296-305.

4. Memom MI, Memom MA: Hepatitis C: an epidemiological review. J Viral Hepat 2002, 9:84-100.

5. Zeuzem S, Andreone P, Pol S, Lawitz E, Diago M, Roberts S, Focaccia R, Younossi Z, Foster GR, Horban A, Ferenci P, Nevens F, Müllhaupt B, Pockros P, Terg R, Shouval D, van Hoek B, Weiland O, Van Heeswijk R, De Meyer S, Luo D, Boogaerts G, Polo R, Picchio G, Beumont M: Telaprevir for retreatment of HCV infection. N Engl J Med 2011, 364(25):2417-2428.

6. Foote BS, Spooner LM, Belliveau PP: Boceprevir: a protease inhibitor for the treatment of chronic hepatitis C. Ann Pharmacother 2011 45(9):1085-1093.

7. Wang F, Wen T, Chen XY, Wu H: Protective effects of pirfenidone on D-galactosamine and lipopolysaccharide-induced acute hepatotoxixity in rats. Inflamm Res 2008, 57:183-188.

8. Tsuchiya H, Kaibori M, Yanagida H, Yokoigawa N, Kwon AH, Okuma T, Kamiyama Y: Pirfenidone prevents endotoxin-induced liver injury after partial hepatectomy in rats. J Hepatol 2004, 40:94-101.
9. Garcia-Benavides L, Hernandez I, Sandoval A, Salazar A, Garcia J, Vera J, Grijalva G, Muriel P, Margolin S, Armendariz-Borunda J: Pirfenidone effectively reverses experimental liver fibrosis. J Hepatol 2002, 37:797-805.

10. Di Sario A, Bendia E, Macarri G, Candelaresi C, Taffetani S, Marzioni M, Omenetti A, De Minicis S, Trozzi L, Benedetti A: The anti-fibrotic effects of pirfenidone in rat liver fibrosis is mediated by downregulation of procollagen alpha 1(l), TIMP-1 and MMP2. DigLiverDis 2004, 36(11):744-751.

11. Armendariz-Borunda J, Islas-Carbajal MC, Meza-Garcia E, Rincon AR, Lucano S, Sandoval AS, Salazar A, Berumen J, Covarrubias A, Arechiga G, Garcia L: A pilot study in patients with established advanced liver fibrosis using pirfenidone. Gut 2006, 55(11):1663-1665.

12. McCaughan GW, George J: Fibrosis progression in chronic hepatitis C virus infection. Gut 2004, 53:318-321.

13. Ortiz V, Berenguer M, Rayon JM, Carrasco D, Berenguer J: Contribution of obesity to hepatitis C-related fibrosis progression. Am J Gastroenterol 2002, 97:2408-2414.

14. Hézode S, Roudot-Thoraval F, Nguyen S: Daily cannabis smoking as a risk factor for progression of fibrosis in chronic hepatitis C. Hepatology 2005, 42:63-71.

15. Zampino R, Marrone A, Restivo L, Guerra B, Sellitto A, Rinaldi L: Chronic HCV infection and inflammation: clinical impact on hepatic and extra-hepatic manifestations. World J Hepatol 2013, 5(10):528-540.

16. Mallat A, Lotersztajn S: Endocannabinoids and Liver Disease I: Endocannabinoids and their receptors in the liver. Am J Physiol Gastrointest Liver Physiol 2008, 294:9-12.

17. Tam J, Liu J, Mukhopadhyay B, Cinar R, Godlewski G, Kunos G: Endocannabinoids in liver disease. Hepatology 2011, 53:346-355.

18. Siegmund SV, Schwabe RF: Endocannabinoids and liver disease. II. Endocannabinoids in the pathogenesis and treatment of liver fibrosis. Am J Physiol Gastrointest Liver Physiol 2008, 294(2):357-362.

19. Julien B, Grenard P, Texeira-Clerc F, van Nhieu JT, Li L, Karsak M, Zimmer A Mallat A, Lotersztajn S: Antifibrogenic role of the cannabinoid receptor CB2 in the Liver. Gastroenterology 2005, 128:742-755.

20. Parfieniuk A, Flisiak R: Role of cannabinoides in chronic liver diseases. World J Gastroenterol 2008, 28:14(40):6190-6114.

21. Muñoz-Luque J, Ros J, Fernández-Varo G, Tugues S, Morales-Ruiz M, Alvarez CE, Friedman SL, Arroyo V, Jimenez W: Regression of fibrosis after chronic stimulation of cannabinoid CB2 receptor in cirrhotic rats. J Pharmacol ExpTher 2008, 324(2):475-483.

22. Sharma K, IX JH, Mathew AV, Cho M, Pflueger A, Dunn SR, Francos B, Sharma S, Falkner B, McGowan TA, Donohue M, Ramachandrarao S, Xu R, Fervenza FC, Kopp JB: Pirfenidone for diabetic nephropathy. J Am Soc Nephrol 2011, 22(6):1144-1151.

23. King Talmadge E, Bradford Williamson Z, Castro-Bernardini S, Fagan Elizabeth A, Glaspole I, Glassberg Marilyn K, Gorina E, Hopkins Peter M, Kardatzke D, Lancaster L, Lederer David J, Nathan Steven D, Pereira Carlos A, Sahn Steven A, Sussman R, Swigris Jeffrey J, Noble Paul W: A phase 3 trial of pirfenidone in patients with idiopathic pulmonary fibrosis. N Engl J Med 2014, 370:2083-2092.

24. Ishak K, Baptista A, Bianchi L, Callea F, De Groote J, Gudat F, Grootes J, Gudat F, Denk H, Desmet V, Korb G, MacSeweeni RNM, Phillips MJ, Portmannl BG, Paulsen H, Scheuer PJ, Schmid M, Thaler H: Histological grading and staging of chronic hepatitis. J Hepatol 1995, 22(6):696-699.

25. Livak KJ, Schmittgen TD: Analysis of relative gene expression data using real time quantitative PCR and the 2(-Delta Delta $C(T)$ ) Method. Methods 2001, 25(4):402-408

26. De Torres $M$, Poynard T: Risk factors for liver fibrosis progression in patients with chronic hepatitis C. Ann Hepatol 2003, 2(1):5-11.

27. World Health Organization. [http://www.who.int/mediacentre/factsheets/ fs311/en/]

28. Kamath PS, Wiesner RH, Malinchoc M, Kremers W, Therneau TM, Kosberg CL, D'Amico G, Dickson ER, Kim WR: A model to predict survival in patients with end-stage liver disease. Hepatology 2001, 33:464.

29. Texeira-Clerc F, Julien B, Grenard P, Nhieu JT, Deveaux V, Li L, Serriere-Lanneau V, Ledent C, Mallat A, Loterstain S: CB1 cannabinoid receptor antagonism: a new strategy for the treatment of liver fibrosis. Nat Med 2006, 12(6):671-676.

30. Macias-Barragan J, Sandoval-Rodriquez A, Navarro-Partida J, Armendariz-Borunda $\mathrm{J}$ : The multifaceted role of pirfenidone and its novel targets. Fibrogenesis Tissue Repair 2010, 1:3-16.

31. Gancedo M, Ruiz-Corro L, Salazar-Montes A, Rincon AR, Armendáriz-Borunda $\mathrm{J}$ : Pirfenidone in capsular contracture after mammary implantation. Aesth Plast Surg 2008, 32:32-40 
32. Veras-Castillo ER, Cardenas-Camarena L, Lyra-Gonzalez I, Muñoz-Valle JF, Lucano-Landeros S, Guerrero-Santos J, Ganzalez-Ulloa B, Mercado-Barajas JL, Sanchez-Parada MG, Azabache-Wenneceslao R, Armendariz-Borunda J: Controlled clínical trial with pirfenidone in the treatment of breast capsular contracture. Ann Plast Surg 2011. In press.

33. Salazar-Montes A, Ruiz-Corro L, Lopez-Reyes A, Castrejon-Gomez E, Armendariz-Borunda J: Potent antioxidant role of pirfenidone in experimental cirrhosis. Eur J Pharmacol 2008, 24(595):69-77.

34. Nakazato H, Oku H, Yamane S, Tsuruta Y, Suzuki R: A novel anti-fibrotic agent pirfenidone suppresses tumor necrosis factor-alpha at the translational level. Eur J Pharmacol 2002, 20(1-3):177-185.

35. Lyer SN, Gurujeyalakshmi G, Giri SN: Effects of pirfenidone on transforming growth factor-beta gene expression at the transcriptional level in bleomycin hamster model of lung fibrosis. J Pharmacol Exp Ther 1999, 291(1):367-373.

36. Cain WC, Stuart RW, Lefkowitz DL, Starnes JD, Margolin S, Lefkowitz SS: Inhibition of tumor necrosis factor and subsequent endotoxin shock by pirfenidone. Int J Immunopharmacol 1998, 20(12):685-695.

37. Asselah T, Rubbia-Brandt L, Marcellin P, Negro F: Steatosis in chronic hepatitis C: why does it really matter? Gut 2006, 55:123-130.

38. Fartoux L, Chazouillères $O$, Wendum D, Poupon R, Serfaty L: Impact of steatosis on progression of fibrosis in patients with mild hepatitis $C$. Hepatology 2005, 41:82-87.

39. Toyoda M, Kitaoka A, Machida K, Nishinakagawa T, Yada R, Kohjima M, Kato M, Koton K, Sakamoto N, Shiota G, Nakamuta M, Nakashima M, Enjoji M: Association between lipid accumulation and the cannabinoid system in Huh7 cells expressing HCV genes. Int J Mol Med 2011, 27(5):619-624.

40. De Gottardi A, Spahr L, Ravier-Dall'Antonia F, Hadengue A: Cannabinoid receptor 1 and 2 agonists increase lipid accumulation in hepatocytes. Liver Int 2010, 30(10):1482-1489.

41. Westerbacka J, Kotronen A, Fielding BA, Wahren J, Hodson L, Pertila J, Perttilä J, Seppänen-Laakso T, Suortti T, Arola J, Hultcrantz R, Castillo S, Olkkonen VM, Frayn KN, Orešič M, Yki-Järvinen H: Splanchnic balance of free fatty acids, endocannabinoids, and lipids in subjects with nonalcoholic fatty liver disease. Gastroenterology 2010, 139(6):1961-1971.

42. Coppola N, Zampino R, Bellini G, Macera M, Marrone A, Pisaturo M, Boemio A, Nobili B, Pasquale G, Maione S, Adinolfi LE, Perrone L, Sagnelli E, Miraglia Del Giudice E, Rossi F: Association between a polymorphism in cannabinoid receptor 2 and severe necroinflammation in patients with chronic hepatitis C. Clin Gastroenterol Hepatol 2014, 12:334-340.

43. Mendez-Sanchez N, Zamora-Valdés D, Pichardo-Bahena R, Barredo-Prieto B, Ponciano-Rodriguez G, Bermejo-Martínez L, Chavez-Tapia NC, Baptista-González HA, Uribe M: Endocannabinoid receptor CB2 in nonalcoholic fatty liver disease. Liver Int 2007, 27(2):215-219.

doi:10.1186/1471-230X-14-131

Cite this article as: Flores-Contreras et al:: Treatment with pirfenidone for two years decreases fibrosis, cytokine levels and enhances CB2 gene expression in patients with chronic hepatitis C. BMC Gastroenterology 2014 14:131.

\section{Submit your next manuscript to BioMed Central and take full advantage of:}

- Convenient online submission

- Thorough peer review

- No space constraints or color figure charges

- Immediate publication on acceptance

- Inclusion in PubMed, CAS, Scopus and Google Scholar

- Research which is freely available for redistribution 